\section{Sperm Whale Physeter macrocephalus stranded at Devbagh beach, Karwar, western coast of India}

\author{
U.G. Naik ${ }^{1}$, J.L. Rathod ${ }^{2}$ \& S.B. Haragi ${ }^{3}$ \\ 1,2,3 Department of Marine Biology, Karnatak University Post \\ Graduate Centre, Kodibag, Karwar, Uttara Kannada, Karnataka \\ 581303, India \\ Email: ${ }^{1}$ ugnaik66@yahoo.co.in, ${ }^{2}$ jagannathrathod9@gmail. \\ com, ${ }^{3}$ shivu398@yahoo.com
}

Karwar Bay is located in the Arabian Sea on the central western coast of India (14048'05'N \& $\left.74^{\circ} 07^{\prime} 48^{\prime \prime} E\right)$ (Fig. 1), and is known for its rich bio-resources such as crustaceans, mollusks, and fin fishes. This section of the coast is popularly known as the 'mackerel coast'. Rich marine resources like squids, prawns and other invertebrate animals support a very good fishery in this area. In fact, this area is a very good feeding ground for many pelagic fishes as well as marine mammals. It is a breeding and feeding ground for dolphins, porpoises and whales all of which visit this area seasonally.

The cetaceans are a diverse group with fossil evidence dating back more than 50 million years. All living families of toothed whales evolved 5-25 million years ago (Joseph \& Velerie 2005). The Sperm Whale belongs to the sub order Odontoceti, family Physeteridae, and is cosmopolitan in distribution. The species name comes from the presence of spermaceti in its head. It has a large head (one-third of its body length), and the S-shaped blowhole is located very close to the front of the head (Whitehead 2002) on the left side. This gives rise to a distinctive bushy, forward-angled blow.

It is a sexually dimorphic cetacean, although both

Date of publication (online): 26 November 2010

Date of publication (print): 26 November 2010

ISSN 0974-7907 (online) | 0974-7893 (print)

Editor: Luke Rendell

Manuscript details:

Ms \# 02406

Received 19 February 2010

Final received 06 August 2010

Finally accepted 11 November 2010

Citation: Naik, U.G., J.L. Rathod \& S.B. Haragi (2010). Sperm Whale Physeter macrocephalus stranded at Devbagh beach, Karwar, western coast of India. Journal of Threatened Taxa 2(12): 1338-1341.

Copyright: (C) U.G. Naik, J.L. Rathod \& S.B. Haragi 2010. Creative Commons Attribution 3.0 Unported License. JoTT allows unrestricted use of this article in any medium for non-profit purposes, reproduction and distribution by providing adequate credit to the authors and the source of publication.

\section{OPEN ACGESS | FREE DOWNLOAD @) (1) Фு}

sexes are the same size at birth (Shirihai \& Jarrett 2006). Adult male Sperm Whales grow up to $67 \mathrm{ft}$ $(20.5 \mathrm{~m})$ and weigh up to $57,000 \mathrm{~kg}$ (Whitehead 2002). As they grow, mature males typically attain sizes 30 to $50 \%$ bigger and three times as massive as females. Females have longer and more prominent genital slit which encompasses the closer spaced genital and anal openings and is flanked by small slits on each side containing nipples.

Materials and Methods: On 17 September 2009, at $1730 \mathrm{hr}$, a female Sperm Whale was stranded at Devbagh beach (14050'34.97'N \& 7406'47.87'E) about 2km away from the Karwar coast (Fig. 1 \& Image 1). Devbagh beach is located about $1.5 \mathrm{~km}$ northwest of Karwar beach. This beach is covered with casuarina plantations (Equisetifolia sp.) and areas of Ipomea pes-carpe, a sand dune plant. The beach is connected to the mouth of the Kali Estuary in the south and is a known turtle breeding ground. Due to the onset of darkness, morphometric studies could not be made at the time of initial discovery and hence the morphometric study of the stranded sperm whale was done the next morning (Table 2). The tidal amplitude was $0.51 \mathrm{~m}$ at $1548 \mathrm{hr}$ on 17 September 2009 and $0.30 \mathrm{~m}$ on 18 September 2009 at $1430 \mathrm{hr}$. The measurements were taken based on Joseph \& Velerie (2005).

Karwar area air, water temperature and humidity were obtained from the Karwar Meteorological Department. Tidal amplitude data for the study area were procured from the Department of Port, Karwar and are presented in Table 1. Prey catch statistics of Karwar area were obtained from the Karnataka State Fisheries Department, Karwar, India and presented in Table 3.

Results: The mammal was first sighted by fisher folk of the Goa coast (Polem beach), about 8km north of Karwar bay and at that time was active and very close to the shore $(2 \mathrm{~km})$. The next day it was sighted at Karwar

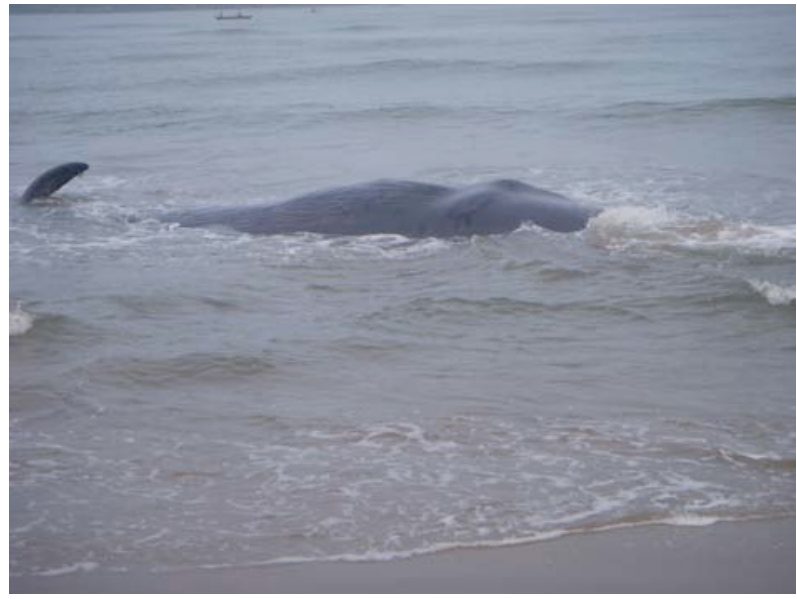

Image 1. Stranded whale on Devbagh shore 


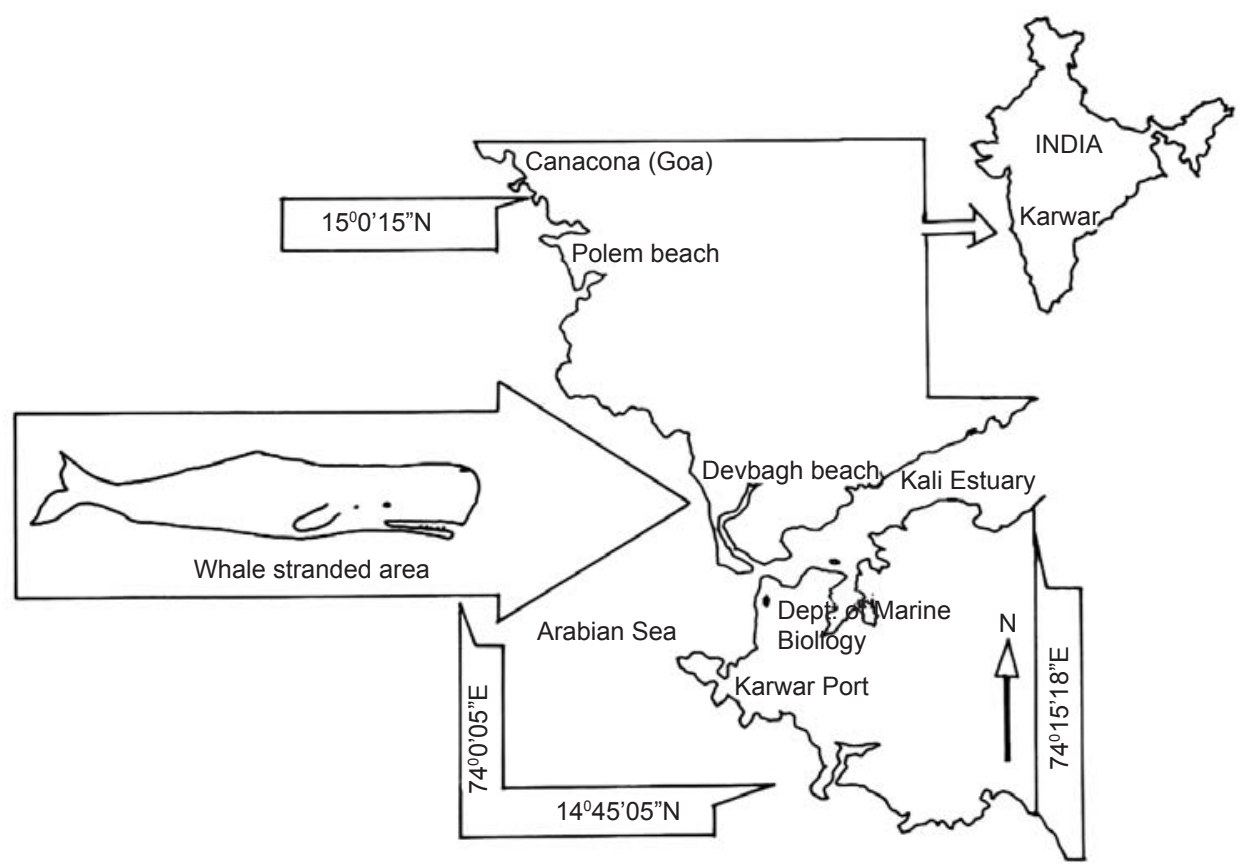

Figure 1. Map showing the location of whale stranding

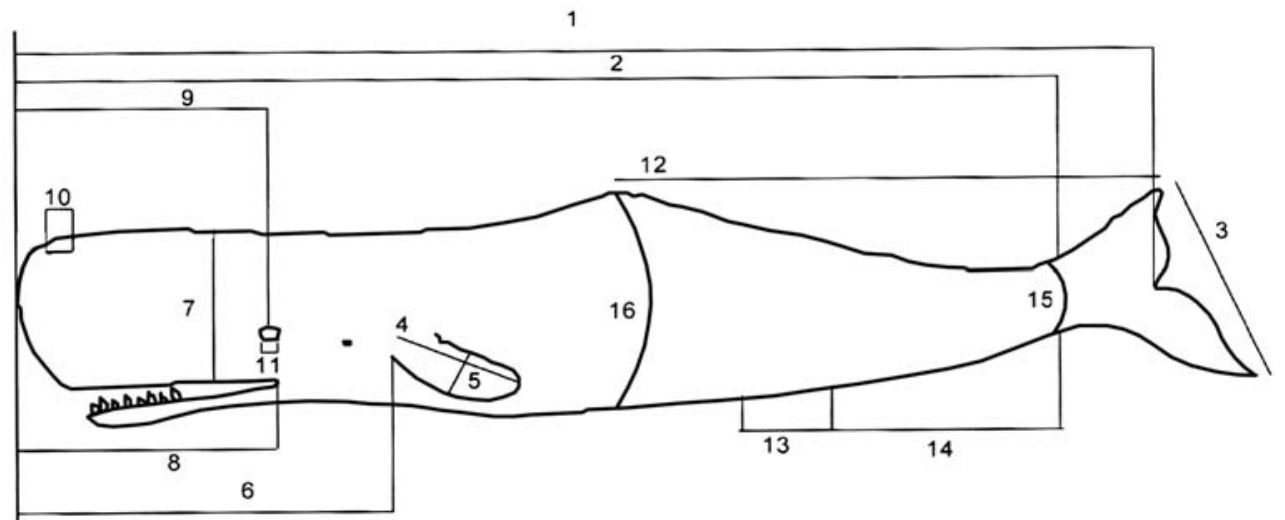

Figure 2. Morphometric parameters of stranded Sperm Whale

1 - Total length; 2 - Standard length; 3 - Fluke width; 4 - Flipper length; 5 - Flipper width; 6 - Snout to anterior insertion of flipper; 7 - Width of the snout: 8 - Snout to angle of mouth; 9 - Snout tip to centre of the eye; 10 - Blow hole length; 11 - Eye diameter; 12 - Dorsal hump to fluke tip; 13 - Length of the genital opening; 14 - Anus to base of the fluke; 15 - Width at the base of tail fluke; 16 - Height of the body

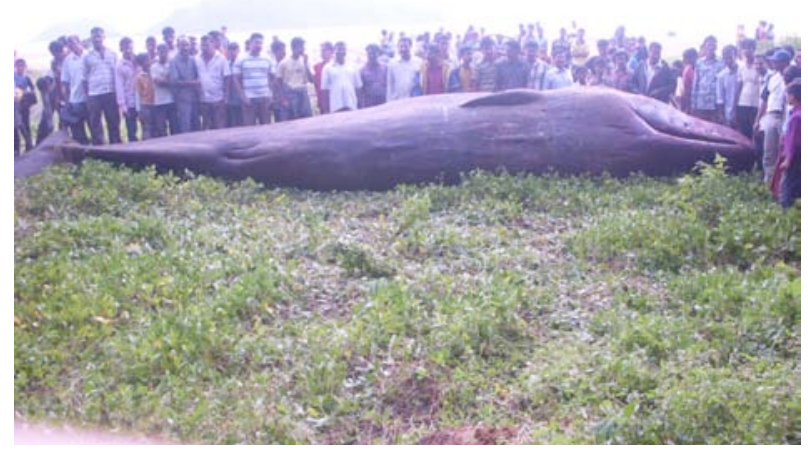

Image 2. Whale dragged on the beach with the help of an earth moving (JCB) machine bay (Devbagh beach) in the evening, and due to the shallow depth was observed to be struggling to go back to the sea. Rescue attempts were made by fishermen and local people along with scientific personnel of the Department of Marine Biology, Post Graduate Centre of Karnatak University, but they did not succeed before the onset of darkness. The next morning the mammal was found dead, lying very close to the shore. There were no physical injuries apparent on the animal's body. Morphological studies were carried out and details are given in Table 2 and Figure 2.

Discussion \& Conclusions: Mortality such as observed here may be due to injury, illness, contaminants, parasites, disease and starvation or anthropogenic 


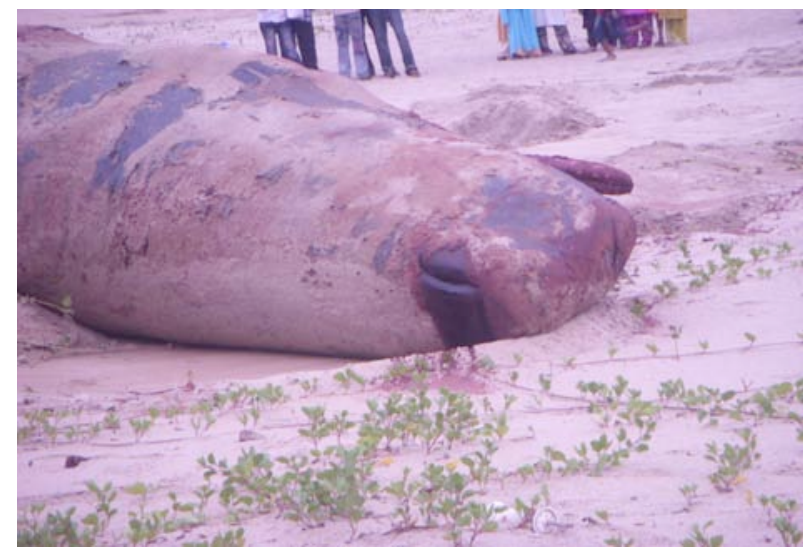

Image 3. Snout portion of the whale showing its blowhole

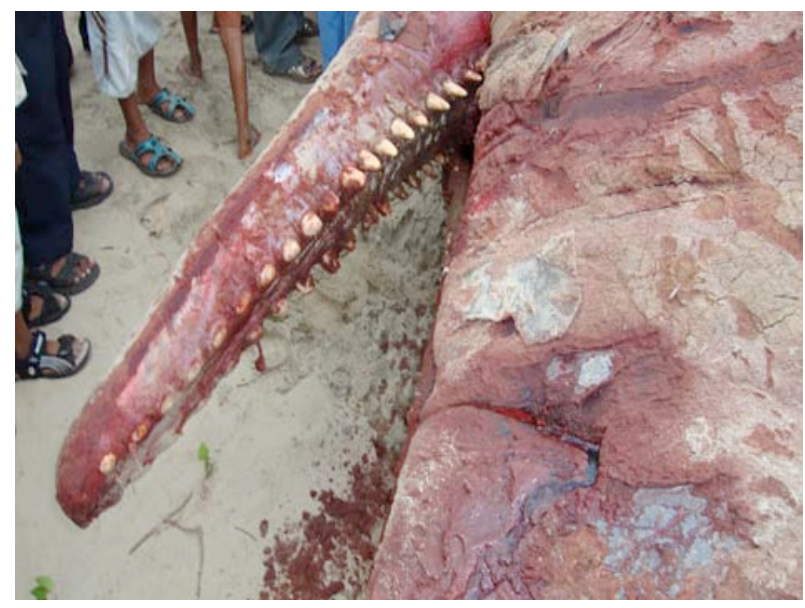

Image 4. Lower jaw of the whale

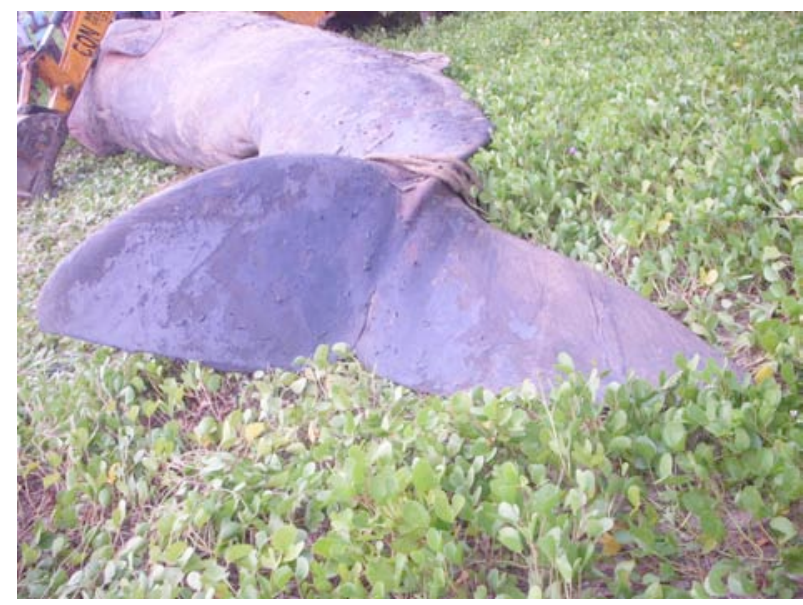

Image 5. Tail fluke
Table 1. Supplementary data

\begin{tabular}{|c|c|c|}
\hline & Parameter & Remarks \\
\hline 1. & $\begin{array}{l}\text { Temperature } \\
\text { Humidity }\end{array}$ & Calm \\
\hline 2. & Tide condition & $\begin{array}{l}0301-0.26 \mathrm{~m} \\
0950-1.87 \mathrm{~m} \\
1548-0.51 \mathrm{~m} \\
2152-1.75 \mathrm{~m}\end{array}$ \\
\hline 3. & Offshore human activity & $\begin{array}{l}\text { Fishing activity: small } \\
\text { mechanized and traditional } \\
\text { fishing }\end{array}$ \\
\hline 4. & Presence of prey fishes & $\begin{array}{l}\text { Squids, cuttle fish, crustaceans, } \\
\text { silver pomfrets, oil sardine and } \\
\text { miscellaneous }\end{array}$ \\
\hline 5. & $\begin{array}{cl}\text { Behaviour } & \\
\text { a. } & \text { pre stranding } \\
\text { b. } & \text { stranding }\end{array}$ & $\begin{array}{l}\text { Milling (17 Sep 2009); 1830hr. } \\
\text { On shore (18 Sep 2009); 0630hr }\end{array}$ \\
\hline 6. & Sample collected for study & Morphometric only \\
\hline
\end{tabular}

Table 2. Morphometric measurements of the stranded Whale

\begin{tabular}{|c|c|c|}
\hline & Particulars & Measurements \\
\hline 1. & Total length & $32.91^{\prime}(395 ")$ \\
\hline 2. & Standard length & $27.66^{\prime}(332 ")$ \\
\hline 3. & $\begin{array}{l}\text { Fluke width } \\
\text { Tail fluke (Caudal) Tip to Fork } \\
\text { L: } \\
\text { R: }\end{array}$ & $\begin{array}{l}8.45^{\prime} \\
4.20^{\prime}\left(50.5^{\prime \prime}\right) ; \text { W:3.16' (38") } \\
4.33^{\prime}\left(52.0^{\prime \prime}\right) ; \mathrm{W}: 3.0^{\prime}\left(36^{\prime \prime}\right)\end{array}$ \\
\hline 4. & Flipper length & $\begin{array}{l}3.37^{\prime}\left(40.5^{\prime \prime}\right) \\
\text { Base: } 1.33^{\prime}\left(16^{\prime \prime}\right)\end{array}$ \\
\hline 5. & Flipper width & Width: $1.41^{\prime}\left(17^{\prime \prime}\right)$ \\
\hline 6. & $\begin{array}{l}\text { Snout to anterior insertion of } \\
\text { flipper }\end{array}$ & $9.25^{\prime}\left(111^{\prime \prime}\right)$ \\
\hline 7. & Width of the snout & $5.41^{\prime}\left(65^{\prime \prime}\right)$ \\
\hline 8. & Snout to angle of the mouth & $3.66^{\prime}\left(44^{\prime \prime}\right)$ \\
\hline 9. & Snout tip to centre of the eye & $6.66^{\prime}\left(80^{\prime \prime}\right)$ \\
\hline 10. & Blowhole length & $1^{\prime}(12 ")$ \\
\hline 11. & Eye diameter & $0.41^{\prime}\left(5^{\prime \prime}\right)$ \\
\hline 12. & Dorsal hump to fluke tip & $14.41^{\prime}(172.92 ")$ \\
\hline 13. & Length of the genital opening & $2.25^{\prime}\left(27^{\prime \prime}\right)$ \\
\hline 14. & Anus to base of the fluke & $11.41^{\prime}\left(137^{\prime \prime}\right)$ \\
\hline 15. & Width at the base of the tail fluke & $4.16^{\prime}(50 ")$ \\
\hline 16. & Height of the body & $5.1^{\prime}(60.01 ”)$ \\
\hline 17. & $\begin{array}{l}\text { Width of the buccal cavity base } \\
\text { (lower jaw) }\end{array}$ & 1.0' (12") \\
\hline 18 & Girth at the lower jaw & $2.25^{\prime}\left(27^{\prime \prime}\right)$ \\
\hline 19. & Width at the base of the tail fluke & $4.16^{\prime}\left(50^{\prime \prime}\right)$ \\
\hline 20. & Width of the tail fluke & $8.45^{\prime}\left(101.5^{\prime \prime}\right)$ \\
\hline
\end{tabular}

External measurements recommended for small cetaceans in the Indian context after Perrin (1975). 
Table 3. Catch statistics of molluscs and crustaceans of Karwar coast (Values in metric tonnes)

\begin{tabular}{|l|c|c|c|c|c|c|}
\hline & \multicolumn{2}{|c|}{ Molluscs } & \multicolumn{4}{c|}{ Prawns } \\
\hline $\begin{array}{l}\text { Period } \\
\text { 2009 }\end{array}$ & Squid & $\begin{array}{c}\text { Cuttle } \\
\text { fish }\end{array}$ & a & b & c & d \\
\hline Jan & 74.0 & 1.0 & 26.70 & 23.0 & 43.0 & 11.0 \\
\hline Feb & 59.0 & 0 & 19.02 & 60.0 & 89.0 & 31.0 \\
\hline Mar & 51.0 & 2.0 & 37.01 & 25.0 & 71.5 & 13.0 \\
\hline Apr & 23.0 & 0 & 12.50 & 43.0 & 50.3 & 13.0 \\
\hline May & 81.0 & 0 & 24.50 & 74.0 & 52.0 & 24.2 \\
\hline Jun & 22.0 & 0 & 135.0 & 19.0 & 99.0 & 9.0 \\
\hline Jul & 0 & 0 & 4.0 & 3.20 & 0.0 & 0 \\
\hline Aug & 16.0 & 0 & 103.0 & 427.5 & 144.0 & 44.0 \\
\hline Sep & 48.0 & 4.0 & 46.7 & 50.0 & 43.0 & 19.0 \\
\hline Oct & 104.7 & 0 & 40.1 & 25.5 & 60.0 & 25.0 \\
\hline
\end{tabular}

Source: Karnataka State Department of Fisheries, Karwar.

a - Penaeus indicus; b - Metapenaeus dobsoni; c - Parapenaeopsis stylifera; d - Metapenaeus affinis

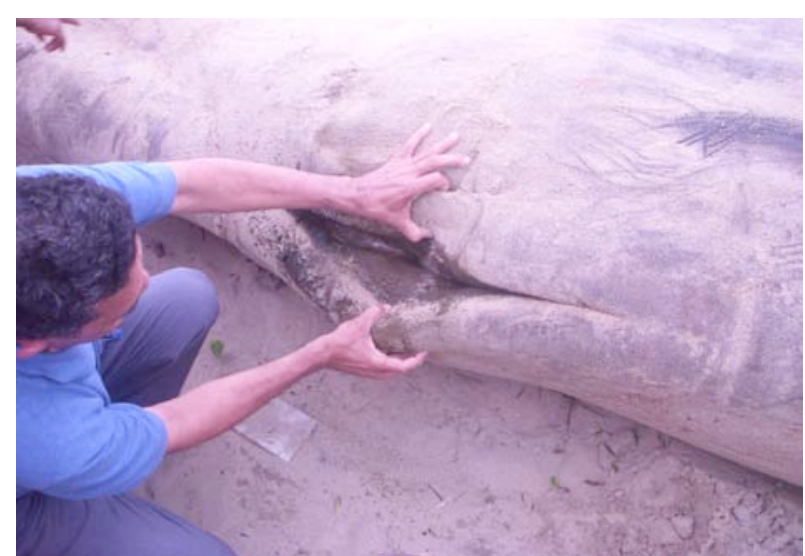

Image 6. Genital and anal openings

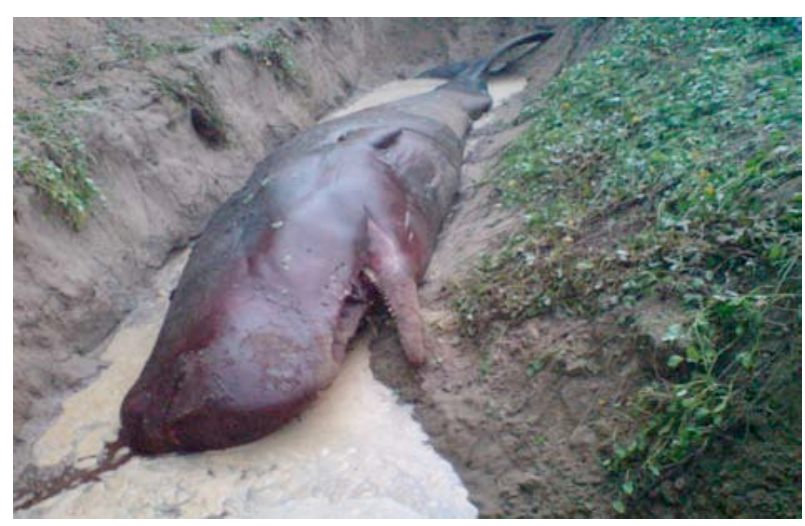

Image 7. Stranded whale buried in the pit to preserve its skeleton causes. The observed stranding correlates with an unusually low tidal amplitude (leading to shallower than normal waters) which may have been a factor in the stranding. This is initially supported by to the lack of external body injury. As this area is not a known breeding ground of this species, the appearance of this sperm whale in this region is probably due to foraging, as squids are the main dietary components of this whale. This might have attracted the whale to these rich waters. The catch statistics of prey species in this region support this interpretation. It was also observed that the previous day and on that day, there was a high catch of squids, prawns, silver pomfrets and small fishes in the particular area, as reported by indigenous fishers. A comparatively high catch of squid, the main diet of the Sperm Whale, was noted in and around Karwar waters during August and September of 2009. In the month of August, the squid catch was 16.0 metric tonnes whereas during September it was 48.0 metric tonnes.

The stranded animal was identified as a female Sperm Whale Physeter macrocephalus (Images 2-6). Later, the whale was buried in the beach (Image 7) to preserve its skeleton for further studies. Physeter macrocephalus is a Vulnerable mammal (IUCN 2008) and the U.S. has listed it as an endangered species.

According to Joseph \& Velerie (2005), saving a livestranded animal is not always possible, but here an attempt was made, which although it failed, provided valuable insight for rescue operations in future.

\section{REFERENCES}

Joseph, R. G. \& J.L. Velerie (2005). Marine Mammals Ashore A Field Guide for Strandings. $2^{\text {nd }}$ Edition. National Aquarium, Baltimore, 371pp.

Perrin, W.F. (1975). Bulletin of Scripps Institute of Oceanography. 21: 3-12. American Cetacean Society Fact Sheet, ACS National H.Q. P.O. Box 1391, San Pedro, CA 90733, USA.

Shirihai, H.S. \& B. Jarrett (2006). Whales Dolphins and Other Marine Mammals of the World. Princeton University Press, Princeton, New Jersey, pp. 21-24.

Whitehead, H. (2002). Sperm Whale Physeter macrocephalus. pp. 1165-1172, In: Perrin, W., B. Würsig \& J. Thewissen (eds.). Encyclopedia of Marine Mammals. Academic Press, San Diego, CA. 